\title{
Social Capital and Firm Performance: Moderating Effect of Environmental Turbulence
}

\author{
Aluisius Hery Pratono ${ }^{1} \&$ Rosli Mahmood ${ }^{2}$ \\ ${ }^{1}$ Faculty of Business and Economics, Universitas Surabaya, Indonesia \\ ${ }^{2}$ College of Business, Universiti Utara Malaysia, Malaysia \\ Correspondence: Aluisius Hery Pratono, Faculty of Business and Economics, Universitas Surabaya, Indonesia. \\ E-mail: hpratono@yahoo.com
}

Received: June 15, 2013 Accepted: August 14, 2014 Online Published: September 29, 2014

doi:10.5539/ass.v10n19p59

URL: http://dx.doi.org/10.5539/ass.v10n19p59

\begin{abstract}
This study aims to determine the moderating effect of environmental turbulence on the relationship among firm performance, entrepreneurial orientation, entrepreneurial management, and social capital. Along with survey on Indonesia SMEs, the finding shows that social capital plays pivotal role on firm performance. This study also provides evident that that environmental turbulence dampens the positive impact of social capital on firm performance. Under low environmental turbulence, social capital has positive impact on firm performance. However, social capital brings negative impact on firm performance during high environmental turbulence. This provides more fundamental issues on intersection between resource based view (RBV) and contingency theory (CT).
\end{abstract}

Keywords: firm performance, social capital, entrepreneurial orientation, entrepreneurial management, environmental turbulence

\section{Introduction}

Small medium enterprise (SMEs) are acknowledged to provide promise of welfare and job creation. Many governments and politicians try to promote SME with various entrepreneurship development programs (Duguh, 2013). Hence, the efforts to boost the performance of SMEs come to a challenging question about what determinant variables influence firm performance of SMEs in the long term.

It appears that entrepreneurial concept goes beyond what strategic management explains about how firms achieve their objectives (Shane, 2012). There has been much debate about the concept of entrepreneurs, which brings into slow development of a cumulative body of knowledge (Rauch et al., 2009). One of the popular views is the concept of Schumpetarian with creative destruction, which refers to innovation as driving forces for the entrepreneur concept and economic development (Betta, Jones, \& Latham, 2010). Another view comes from Kirznerian. This school of thought considers another element of entrepreneurship, namely proactive market-driven behavior to seize business opportunities (Sundqvist et al., 2012). Both innovation and proactive behavior are considered as main element of entrepreneurial orientation, which refers to the best way of firms to achieve goals (Covin \& Wales, 2012).

In the context of internal organization, SMEs tend to suffer from lack of resources, especially tangible asset. In external context, a firm challenges various environmental turbulence, from competitors, buyers and changing technology. Along with limited resources, SMEs need to be more adaptable to respond environmental turbulence (Nunéz \& Lynn, 2012; Coad et al., 2013). Greater environmental turbulence causes gap between marketing capability and market complexity becomes greater (Didonet et al., 2012). To seize business opportunity with limited resources, SMEs rely on social capital to deal with high transaction cost (Clopton, 2011).

This study considers entrepreneurial orientation (EO), entrepreneurial management (EM) and social capital (SC) as main determinants to achieve the goal of firms. Neglecting the moderating variable from previous literatures to explain the impact of such entrepreneurial concept leads a lack of relevance and call for research about a relevant moderating variables (Didonet et al., 2012). To respond such research gap, this research focuses to determine the moderating effect of environmental turbulence (ET) on the impact of entrepreneurial orientation, social capital, and entrepreneurial management on firm performance. 


\section{Literature Review}

This study underpins both resource-based view and contingency theory. The resources based view explains how firms use entrepreneurial orientation, entrepreneurial management and social capital as their valuable resources to achieve the goal, while contingency theory explains how exogenous variable influences the effect of such resources on firm performance.

\subsection{Resource-Based View}

Resource-based view (RBV) highlights transformation of valuable resource to achieve goals. This theory becomes a fertile ground to competitive advantage in which firms rely on their own tangible and intangible resources to transform their short-term competitive advantage into sustainable competitive advantage. This process requires unique resources, which are neither substitutable and removable. This approach is different from competitive based approach, which focus on source of sustainable competitiveness from external environment (Akio, 2005). However, both concepts consider that valuable resources can foster performance greater than average.

As intangible resources, entrepreneurial orientation (EO), entrepreneurial management (EM) and social capital (SC) play pivotal role to boost SME performance (Sciascia, Mazzola, \& Chirico, 2012). The concept of entrepreneurial orientation (EO) refers to the way firms running in the long term with proactiveness, innovativeness, and risk-taking behavior (Covin \& Wales, 2012). Therefore, entrepreneurial management refers to entrepreneurial approaches in management practices, which includes strategic orientation, organization structure, entrepreneurial culture, and reward philosophy (Gürbüz \& Aykol, 2009). Social capital is also considered as valuable resources.

The concept of social capital anchors on social network theory, which explains behavior of social relationship in regards to assessing economic transaction (Jackson, 2008). The networks with external stakeholders come to challenges since market complexity becomes apparent. Then, social capital is crucial to achieve its performance and to survival. This construct refers to source of competitive advantage in generates incomes (Morgan, Vorhies, \& Mason, 2009) with daily cash flow to recover their input cost.

Innovation or new product development process requires combination between firm resources and firm capability. The RBV highlights that innovative in providing superior value to customers is main determinant to gain sustainable competitive advantage (Gupta \& Malhotra, 2013). In the context of SMEs, capability to deal with external shock is crucial to achieve its performance and to survival. This construct refers to source of competitive advantage in generates incomes (Morgan, Vorhies, \& Mason, 2009) with daily cash flow to recover their input cost. To narrow the gap between complexity and firm capability requires continuous process to apply knowledge, skill and resource.

\subsection{Contingency Theory}

Contingency theory rails against the classical management theory from being neglected of contingency factors or external environment. It seems that Classical management theory tends to be biased view against internal organization in order to achieve efficiency through specialization and formalize procedures (Peng \& Sang, 2011) Hence, contingency theory considers that firm's capability to respond business environment determines firm performance (Bell \& Martin, 2012). Hence, flexibility to set organization structure is important issue to deal with environmental turbulence, which implies on new behavior of firms in order to survive (Nunéz \& Lynn, 2012).

Capability to deal with business environment is associated with knowledge management system, which requires firms to carry out consumer intelligence. The intelligence strategy provides information in which firms can change strategy to meet various level of environmental turbulence (Lowe, Lowe, \& Lynch, 2010). Contingency model considers that firms can gain knowledge through assessing their business environment and set strategy, which are appropriate for each level of environmental turbulence (Johannesson \& Palona, 2010). Indeed, environmental turbulence refers to various dynamic environmental settings in which technology, product preferences and competition intensity are dramatically changing.

Contingency effect can be environmental turbulence, which refers to the hostility of business environment, which can turn into various level of uncertainty (Zhang \& Duan, 2010). This concept constitutes into three elements, i.e. technology turbulence, market turbulence, and competition turbulence. Responsiveness as crucial for SMEs to deal with customer needs within technological turbulence (Didonet, Simmons, Villavicencio, \& Palmer, 2012). Typically, SMEs have lack of capacity to anticipate the turbulence on account of poor scanning of accurate and reliable information about the industry condition (Wang \& Fang, 2012). Market turbulence is about the level of dynamic composition of customers and their preferences. This causes increasing uncertainty 
due to changing customer's preference. The respond to market turbulence can be associated with business expansion through the advantage of larger business with market power and economies of scale (Didonet, Simmons, Villavicencio, \& Palmer, 2012). Higher levels of market turbulence bring about high uncertainty due to less accurate forecast, then firms may back off to invest. Firm with capacity to develop their technology to respond the negative impact of marketing turbulence will be able to survive through demand chain visibility to manage activities better (Iyer, 2011).

\subsection{Hypothesis Development}

The main proposed model tries to explain firm performance and its determinants, which includes entrepreneurial orientation (EO), entrepreneurial management (EM) and social capital (SC). Construct of entrepreneurial orientation (EO) has emerging since decades, when Miller and Friesen (1978) try to identify the driving forces of success firms, i.e. innovativeness, risk-taking behavior, and proactiveness. Hence, EM is considered as mechanism for entrepreneurial firms with innovation and opportunity orientation, which embedded in strategy, organization structure, and people (Gürbüz \& Aykol, 2009).

A number of studies provide evident that EO has positive impact on FP (Moreno \& Casilas, 2008; Simon, Stanchel, \& Covin, 2011). Firms with initiative to enhance its EO may achieve their FP in the short term, while long term competitive advantage becomes apparent in firms with radical EO (Bojica, Fuentes, \& Gómez-Gras, 2011). Conversely, the extended empirical studies no strong relationship between EO and FP. This occurs to new firms with experiences no more than eleven year (Runyam, Ge, Dong, \& Swinney, 2008). Complicated relationship between risk and failure also explains the insignificant relationship between EO and FP (Andersén, 2010). In addition, Kreiser et al. (2013) argues the U-shape relationship between EO and FP explains negative relationship occures during the earlier years, while another reason comes from unobserved variables, such as business environment turbulence (Kreiser, Marino, Kuratno, \& Weaver, 2013).

\section{Hypothesis 1: Entrepreneurial orientation has positive effect on firm performance}

Another entrepreneurial concept comes from entrepreneurial management (EM), which is expected to have significant impact on FP (firm performance). This construct constitutes four elements, such as strategy orientation, entrepreneurial culture, organization structure and reward system. EM is expected to provide positive impact on FP (Bradley, Wiklund, \& Shepherd, 2011). In addition, combination between EM and EO enable firms to yield the best FP (Gürbüz \& Aykol, 2009). However, some elements of EM may have different impact. Overiding focus may causes no significant impact of entrepreneurial culture on FP (Slater, Olson, \& Finnegan, 2011). The complicated dimension of FP may provide poor relationship between EM and FP (Urkurt, Kumar, Kimzan, \& Eminoglu, 2013). Reward philosophy may have indirect effect on FP (Wei, Frankwick, \& Nguyen, 2012).

\section{Hypothesis 2: Entrepreneurial management has positive effect on firm performance}

Turning to social network theory, sound performance may occur with strong SC through valuable work environment (Duffy, Scott, Shaw, Tepper, \& Aquino, 2012) and life satisfaction of stakeholders (Lim \& Putnam, 2010). However, different phase of firms growth may comes with different relationship between SC and FP. Overhead cost to maintain greater social capital is one of the reasons why the relationship between SC and FP is not always positive (Alguezaui \& Filieri, 2010). At start-up level, firms invest a lot of resources to enhance social networks, which implies on poor FP in the sort term (Pirolo \& Presutti, 2010). In addition, spillover information, which comes from greater SC may bring negative effect on FP (Ahmadi, 2011). This implies on the effectiveness of decision in SMEs, which depend on the level of connectivity with various stakeholders (Jansen et al., 2011).

\section{Hypothesis 3: Social capital has positive effect on firm performance}

Environmental turbulence (ET) is considered to come with moderating effect that changes the direction of relationship between EO and FP. Moderating effects of environment turbulence come up with multi faceted effect, which can be positive or negative. Negative mediating impact of ET on FP springs from unanticipated environmental turbulence (Wang \& Fang, 2012). That technological turbulence provides moderating effect in the relationship between EO and technology commercialization. Allocate more resources to addopt new technology is considered as a risk factor under high ET ( $\mathrm{Li}, \mathrm{Guo}, \mathrm{Liu}, \& \mathrm{Li}, 2008)$. Firms with greater EO tends to be more proactive in low ET and prefer to focus on investment during high turbulence (Sundqvist, Kyläheiko, \& Cadogan, 2012).

Hypothesis 4: Environmental turbulence has moderating impact on the relationship between entrepreneurial orientation and firm performance 
Environmental turbulence (ET) can provides both opportunity and threats in which EM style can take for grant it in such condition. SMEs with greater EM tend to adopt informal system may have more opportunity gain benefit from environmental turbulence (Didonet, Simmons, Villavicencio, \& Palmer, 2012). To some extend, flexibility and informal style enhances the capability of firms to deal with ET, which then followed by positive impact on FP. Specifically, technology turbulence foster 'energetic will', which enable firms to create new innovation (Bertta, Jones, \& Latham, 2010). On the other hand, EM may be no more relevant under high ET. Formalized structure and centralized authority is considered to provide more effective to achieve greater FP under high ET. ET can have insignificant impact on FP, especially for firm which prefers to focus on building time under high ET (Chi \& Shun, 2013).

Hypothesis 5: Environmental turbulence has moderating impact on the relationship between entrepreneurial management and firm performance

ET may have different impact on the relationship between SC and FP. ET brings more complexity of social capital, which implies on the way firm improve supply chain (Nagarajan et al., 2013). Firms with greater SC may achieve the goals under low environmental turbulence. Under environmental turbulence, social capital still plays pivotal role on FP (Tang et al., 2010; Chawla et al., 2012). Wang and Fang (2012) indicates curvilinear relationship between EO and FP.

Hypothesis 6: Environmental turbulence has moderating impact on the relationship between social capital and firm performance.

Firms with standardized activities and centralization may increase efficiency during low environmental tubule. However, greater turbulence sparks off poor efficiency in such organization structure (Chi \& Shun, 2013).

\section{Method}

This study uses quantitative method. The approach will be explained in these following steps.

\subsection{Quantitative Approach}

This study uses quantitative method with cross-section design. The information analysis springs from a list of questionnaires, which distributed through random sampling approach to obtain maximum respond rate. The questionnaires design adapts from some literatures with aims to collect accurate information from respondents.

\subsection{Sample}

The sampling frame is derived from SMEs database published by City Government of Surabaya. A list of questionnaires are send to 700 respondents, which randomly selected from 35,489 SMEs population. The definition of SMEs refers to firms with annual sales less than USD5 million and asset no more than USD1 billion. Hence, 390 SMEs owner managers contribute to this study, which is relevant for such observed population (Krejcie \& Morgan, 1970).

\subsection{Measures}

The measures of FP with subjective approach adapt from Aziz and Mahmood (2011). The subjective approach is part of research strategy to deal with viable financial report of SMEs (Sheppard \& Radulovich, 2010). The EO measures addapt from Lumpkin, Cogliser, and Scheneider (2009), which considers the three original factors, i.e. risk taking behavior, proactive, and innovativeness (Miller \& Friesen, 1978). The study considers structure, trust and cognition as the elements of SC (Parra-Requena, Ruiz-Ortega, \& García-Villaverde, 2011). EM adapts from Gürbüz and Aykol (2009) and Bradley et al. (2012). ET comprises three elements (technological turbulence, market turbulence, and competitive turbulence), which adapts from Zhang and Duan (2010) and Didonet et al. (2012). The questions are designed with seven point Likert scaling (1-7 ratings).

\subsection{Research Design}

This study uses PLS (Partial Least Square) to test the hypothesis. This approach maximizes the variance with an iterative sequence of ordinary least square to estimate the coefficient of independent variable. This implies that PLS-SEM is more relevant for application where strong assumption of multivariate normality can't be fully met (Hair, Sarstedt, Ringle, \& Mena, 2012). However, this approach has disadvantage, especially on model fit measures and no classical inferential framework (Henseler, 2010).

\subsection{Moderating Effect}

Moderating variable may bring change direction on the slope or coefficient of independent variables. Moderating effect may dampen the positive effect of the independent variables on FP (Henseler \& Fassott, 2010). In 
structural equation model (SEM), the formulation of moderating effect of environmental turbulence (ET) on the relationship between social capital (SC) and firm performance (FP) can be expressed as bellow:

$$
\begin{aligned}
& F P=a+b S C \\
& F P=a+(b+d . E T) . S C+c E T \\
&=(a+c . E T)+(b+d \cdot E T) . S C
\end{aligned}
$$

\section{Results}

In the Results section, summarize the collected data and the analysis performed on those data relevant to the discourse that is to follow.

\subsection{Data description}

Table 1 shows that the latent variables are in the range of 4 and 5 with seven point Likert scaling (1-7 ratings). This indicates that the observed firms have performance slightly greater than moderate. Similarly, the respondents also have EO and EM slightly greater than moderate, while SC has greater average than other variables. The coefficients of Pearson correlation show all dependent variables have significant correlation with FP. The greatest correlation among independent variables occurs between SC and EM with 0.517.

Table 1. Data description and correlation

\begin{tabular}{cccccccc}
\hline Variables & Average & Std.Dv & 1 & 2 & 3 & 4 & 5 \\
\hline 1. FP & 4.8084 & 1.32610 & 1.00 & & & & \\
2. EO & 4.2442 & .97187 & $.224^{*}$ & 1.00 & & & \\
3. EM & 4.8444 & 1.17275 & $.308^{*}$ & $.294^{*}$ & 1.00 & & \\
4. SC & 5.2423 & 1.52104 & $.649^{*}$ & $.228^{*}$ & $.517^{*}$ & 1.00 & \\
5. ET & 4.1718 & 1.72796 & $.527^{*}$ & $.170^{*}$ & $.355^{*}$ & $.525^{*}$ & 1.00 \\
\hline
\end{tabular}

* : significant at $5 \%$

Table 2 shows a summarize of a set of variables structure. As a set of measures represent one underlying construct, the factor analysis addresses challenge question on how well the measures represent construct and how many items represent a construct. Hence, the result will be a small number variables, based on condensing information derived from the measures (de Velis, 2012). This study considers average variance extracted (AVE), composite reliability (CR) and Cronbach's alpha (CA). It appears that all latent variables have AVE greater than 0.50 , which implies that convergent validity is accepted. Thereafter, CRs are greater than 0.80 , indicate that measures are reliable, while CAs are greater than 0.7 , which shows that the measures of all latent variables are consistent.

Table 2. Structure of variables

\begin{tabular}{ccccc}
\hline Variables & AVE & CR & CA & Communality \\
\hline EM & 0.556893 & 0.833045 & 0.730651 & 0.556893 \\
EM ${ }^{*}$ ET & 0.704349 & 0.966136 & 0.961635 & 0.704349 \\
EO & 0.646946 & 0.845859 & 0.734535 & 0.646946 \\
EO ${ }^{*}$ ET & 0.783325 & 0.970175 & 0.965428 & 0.783325 \\
ET & 0.783126 & 0.915483 & 0.861749 & 0.783126 \\
FP & 0.652084 & 0.929044 & 0.910873 & 0.652084 \\
SC & 0.735792 & 0.917607 & 0.880314 & 0.735792 \\
SC ${ }^{*}$ ET & 0.792853 & 0.978686 & 0.976255 & 0.792853 \\
\hline
\end{tabular}

\subsection{Path Analysis}

Table 2 shows bootstrap output, which provides evident that some proposed independent variables have significant impact on firm performance. Both entrepreneurial orientation (EO) and entrepreneurial management (EM) have no significant impact on firm performance (FP) with p $>.05$. Consequently, H1 and H2 are rejected. On the other hand, social capital (SC) has significant impact on firm performance (FP) with $t=3.09$ and $p<.05$, which implies that $\mathrm{H} 3$ is accepted. 
Table 3. Bootstrap output

\begin{tabular}{cccccc}
\hline & $\begin{array}{c}\text { Original Sample } \\
(\mathrm{O})\end{array}$ & $\begin{array}{c}\text { Sample Mean } \\
(\mathrm{M})\end{array}$ & $\begin{array}{c}\text { Standard } \\
\text { Deviation } \\
(\text { STDEV })\end{array}$ & $\begin{array}{c}\text { Standard Error } \\
(\text { STERR })\end{array}$ & $\begin{array}{c}\text { T Statistics } \\
(|\mathrm{O} / \mathrm{STERR}|)\end{array}$ \\
\hline EM -> FP & 0.089792 & 0.097820 & 0.270247 & 0.270247 & 0.332259 \\
EM * ET -> FP & 0.062205 & 0.019939 & 0.513444 & 0.513444 & 0.121152 \\
EO -> FP & -0.308232 & -0.279068 & 0.266303 & 0.266303 & 1.157447 \\
EO ET -> FP & 1.038375 & 0.986823 & 0.495630 & 0.495630 & 2.095062 \\
ET -> FP & 0.731968 & 0.785835 & 0.323182 & 0.323182 & 2.264876 \\
SC -> FP & 1.091013 & 1.071188 & 0.289211 & 0.289211 & 3.772378 \\
SC * ET -> FP & -1.789107 & -1.748776 & 0.576382 & 0.576382 & 3.104029 \\
\hline
\end{tabular}

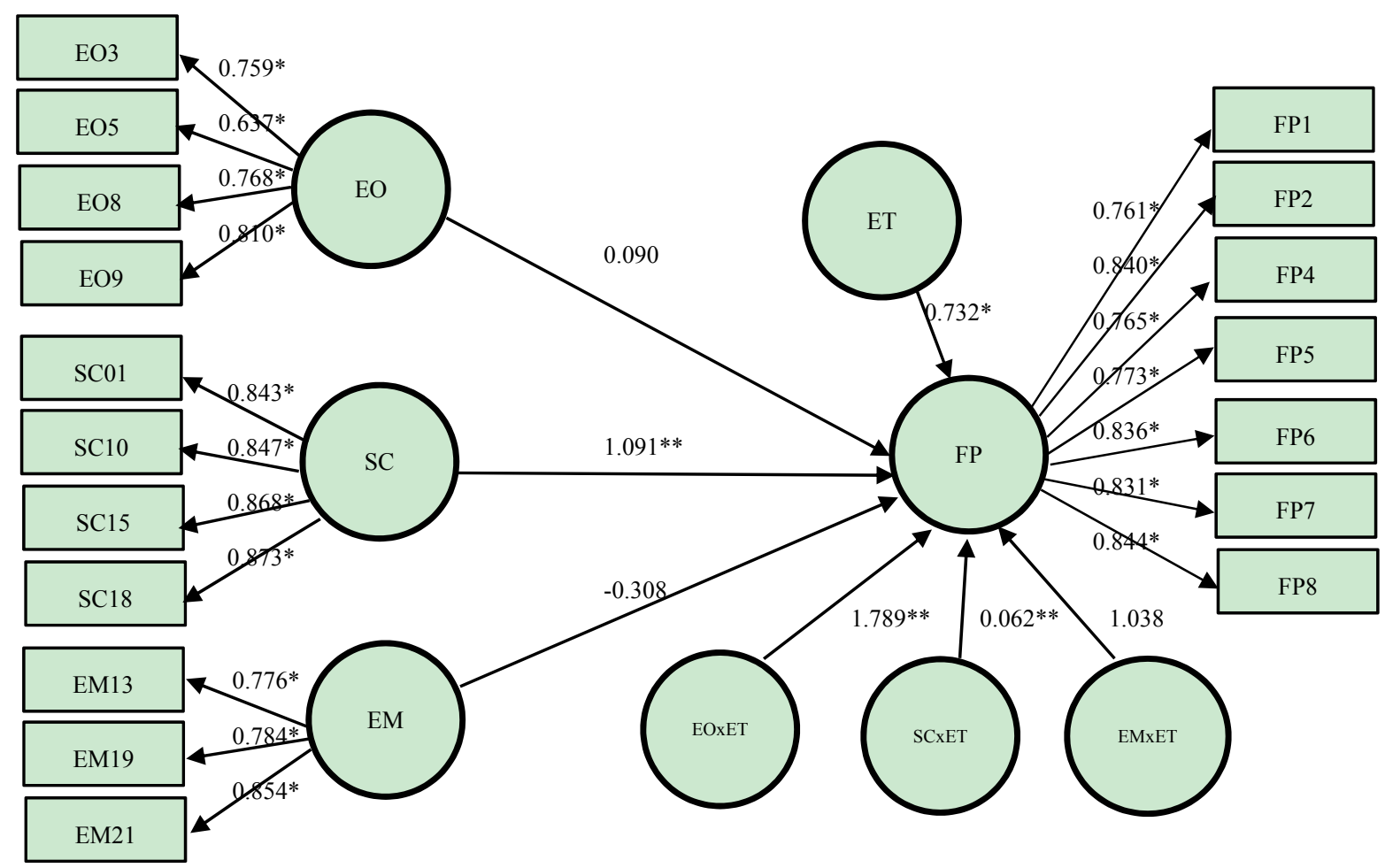

Figure 1. Output of PLS

$*$ = significant at alpha $<.05, * *$ significant at alpha $<.01$

\subsection{Moderating Test}

To identify the moderating effect of ET (H4, H5 and H6), it necessary to considers the impact of independent variables, moderating variable, and interaction. Interaction arises to explain how simultaneous influence of two variable. Since $\mathrm{H} 1$ and $\mathrm{H} 2$ are rejected, then $\mathrm{H} 4$ and $\mathrm{H} 5$ are also rejected. Figure 1 shows negative coefficient, which indicates that SC has negative impact on FP. This result support the previous literature (Pirolo, 2010 and Ahmadi (2011). Bootstrap output also shows that environmental turbulence (ET) has significant impact on firm performance with $\mathrm{t}=1.89$ and alpha $<0.05$ (second degree of significance level). In addition, SC $\mathrm{x}$ ET also has significant impact with $\mathrm{t}=3.035$ and alpha $<0.01$, which implies that $\mathrm{H} 6$ is accepted.

Figure 2 shows how moderating effect of ET influences the impact of SC on FP. This indicates that H6 is accepted, which means that the different level of ET has different impact on the relation between SC and FP. The finding shows that ET dampens the positive impact of SC on FP. Under low ET, SC provide positive impact on 
FP. This indicates that firms can gain greater performance with greater investment in SC with certain condition, low environment turbulence. However, SC has negative impact on FP during high ET.

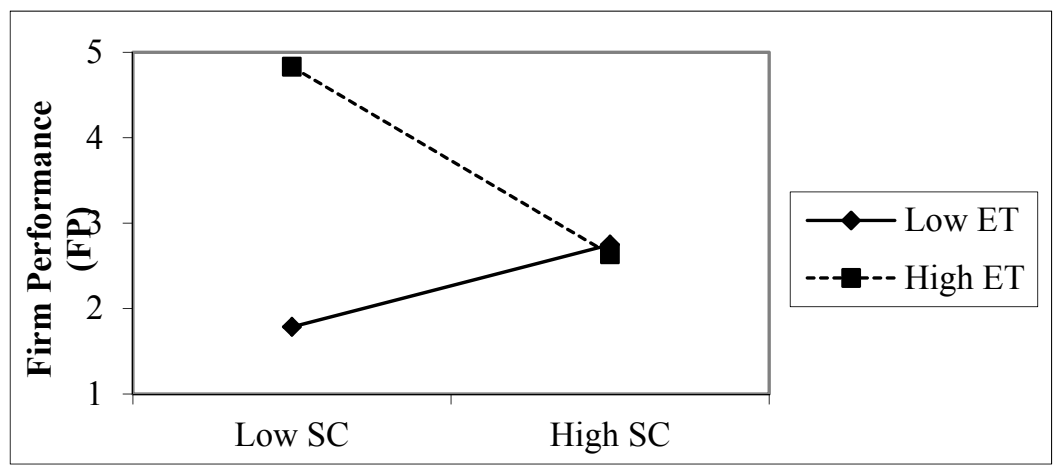

Figure 2. Moderating effect of environmental turbulence

\section{Discussion}

The social capital as valuable resource plays pivotal role on firm performance. As such resource for cohesion and structural relationship is considered with investment in social networks, the result provides evident that in the context of Indonesia SMEs, social with strong internal and external networks has negative impact on firm performance. From resource-based view, this study indicates that investment in such valuable resources does not foster firm performance during high environmental turbulence. However, during low environmental turbulence, firms with greater social capital experiences greater firm performance. On the other hand, under high environmental turbulence, firm with greater social capital suffers from poor firm performance. This finding is more relevant with Tang et al. (2010) and Chawla et al. (2012).

The evidence suggests that the benefit of investment in social capital will yield during the low environmental turbulence. Though technological can provide more opportunities in industry, but pressure of greater technology turbulence causes many SMEs suffers due to their poor capacity to adopt new technology. Hence, responsiveness is crucial for SMEs to deal with customer needs within technological turbulence. In addition, higher levels of market turbulence bring about uncertainty to SMEs due to less accurate forecast, hence they can't respond dynamic composition of customers and their preferences. This causes increasing uncertainty due to heightened market turbulence in which firms need to deal with. Marketing operations is necessary to respond the changing customer's preference (Zhang \& Duan, 2010). This effort to respond market turbulence can be associated with business expansion in which not all of SMEs can do (Didonet et al., 2012). In the context of competitiveness, the more new entrants in the industry, the more pressure on SMEs to worry about their competitiveness due to many new entrant in their industry. In the short-run entry may, competition brings about price competition and sparks off lower revenues for incumbents firms. Competitive intensity is the extent to which companies face competition over the output market resources they need to live and grow.

It appears that both entrepreneurial orientation (EO) and entrepreneurial management (EM) have no significant impact on firm performance (FP). There are some alternative reasons which may provide an answer. First, it shows that there is no direct effect of EO on FP, as well as effect of EM on FP. Hence, the future study should identify some mediating variable which can explain the generative process of such entrepreneurial resources to the competitiveness of SMEs. Secondly, the insignificant impact of EO on FP come from lack of identification the elements of EO, such as relationship between risk and failure (Andersén, 2010).

The study has some limitations, which needs to be addressed in the future research. First, the sample frame is limited to SMEs located in the Surabaya, Indonesia, the second big metropolitan area. The different socio economic culture might provide different impact on firm performance. Second is only one respondent to each firm who contribute to this research. Everyone in family businesses has different interest, such as the first and second generation of owner managers, which implies on difference preferences. Third, this study uses cross section data, which seems to provide snap-shot observation. It would be worthwhile to study origin of dynamic environmental turbulence in time series context, which can support this study regarding the magnitude of environmental turbulence. 


\section{Conclusion}

The study confirms the mediating effect of environmental turbulence on the relationship between social capital and firm performance. This finding provides more fundamental issues on both resource based view (RBV) and contingency theory (CT) that the impact of resource deployment yield greater performance under certain condition, such as low environmental turbulence. It has been confirmed that SMEs with more investment in social capital are generally suffering from environmental turbulence because of their capacity for adaptation to the dynamic business environment. In addition, this shows that both entrepreneurial orientation and entrepreneurial management have no significant impact on firm performance, which is almost unexplored in the context of SMEs.

\section{References}

Aziz, S., \& Mahmood, R. (2011). The relationship between business model and performance of manufacturing small and medium enterprises in Malaysia. African Journal of Business Management, 5(22), 8918-8932.

Ahmadi, A. (2011). Social capital for knowledge management. Interdiciplinary Journal of Contemporary Research Business, 3(7), 957-972.

Akio, T. (2005). The critical assessment of the resource-based view of strategic management: The source of heterogenity of the firm. Ritsumeikan International Affair, 3, 125-150.

Alguezaui, S., \& Filieri, R. (2010). Investigating the role of social capital in innovation: sparse versus dense network. Journal of Knowledge Management, 14(6), 891-909. http://dx.doi.org/10.1108/13673271011084 925

Andersén, J. (2010). A critical examination of the EO-performance relationship. International Journal of Entrepreneurial Behaviour \& Research, 16(4), 309-328.

Audretsch, D. (2012). Entrepreneurship research. Management Decision, 50(5).

Baker, W., \& Sinkula, J. (2009). The complementary effects of market orientation and entrepreneurial orientation on profitability in small businesses. Journal of Small Business Management, 47(4), 443-464. http://dx.doi.org/10.1111/j.1540-627X.2009.00278.x

Bell, R., \& Martin, J. (2012). The relevance of scientific management and equity theory in everyday managerial communication situations. Journal of Management Policy and Practice, 13(3), 106-115.

Bertta, M., Jones, R., \& Latham, J. (2010). Entrepreneurship and the innovative self: A Schumpeterian reflection. International Journal of Entrepreneurial Behaviour \& Research, 16(3), 229-244. http://dx.doi.org/10.1108/ 13552551011042807

Bojica, A., Fuentes, M., \& Gómez-Gras, J. (2011). Radical and incremental entrepreneurial orientation: The effect of knowledge acquisition. Journal of Management \& Organization, 17(3), 326-343. http://dx.doi.org/10.5172/jmo.2011.17.3.326

Bradley, S., Wiklund, J., \& Shepherd, D. (2011). Swinging a double-edged sword: The effect of slack on entrepreneurial management and growth. Journal of Business Venturing, 26(5), 537-553. http://dx.doi.org/10.1016/j.jbusvent.2010.03.002

Chawla, C., Mangaliso, M., Knipes, M., \& Gauthier, J. (2012). Antecedents and implications of uncertainty in management. Journal of Management History, 18(2), 200-218.

Chi, T., \& Shun, Y. (2013). Development of firm export market oriented behavior: Evidence from an emerging economy. International Business Review, 22(1), 339-350. http://dx.doi.org/10.1016/j.ibusrev.2012.05.003

Clopton, A. (2011). Social capital and team performance. Team Performance Management, 17(8), 369-381.

Covin, J., \& Wales, W. (2012). The measurement of entrepreneurial orientation. Entrepreneurship Theory and Practice, 36(4), 677-702.

Coad, A., Frankish, J., Robert, R., \& Storey, D. (2013). Growth paths and survival chances: An application of Gambler's Ruin theory. Journal of Business Venturing, 28(5), 615-632.

de Velis, R. (2012). Scale Development: theory and application. Los Angeles: Sage Publication.

Duffy, M., Scott, K., Shaw, J., Tepper, B., \& Aquino, K. (2012). A social context model of envy and social undermining. Academy of Management Journal, 55(3), 643-666. http://dx.doi.org/10.5465/amj.2009.0804

Duguh, S. (2013). Entrepreneurship and small business: Strategic approach to alleviating poverty and corruption 
in Nigeria. GSTF Business Review, 3(1), 57-66.

Didonet, S., Simmons, G., Villavicencio, G., \& Palmer, M. (2012). The relationship between small business market orientation and environmental uncertainty. Marketing Intelligence \& Planning, 30(7), 757-779.

Gürbüz, G., \& Aykol, S. (2009). Entrepreneurial management, entrepreneurial orientation and Turkish small firm growth. Management Research News, 32(4), 321-336. http://dx.doi.org/10.1108/01409170910944281

Garg, S. (2013). Venture boards: Distinctive monitoring and implications for firm performance. Academy of Management Review, 38(1), 90-108.

Gupta, S., \& Malhotra, N. (2013). Marketing innovation: A resource-based view of international and local firms. Marketing Intelligence \& Planning, 31(2), 111-126

Iyer, K. (2011). Demand chain collaboration and operational performance: Role of IT analytic capability and environmental uncertainty. Journal of Business \& Industrial Marketing, 26(2), 81-91. http://dx.doi.org/10. $1108 / 08858621111112267$

Hair, J., Sarstedt, M., Ringle, C., \& Mena, J. (2012). An assessment of the use of partial least squares structural equation modeling in marketing research. Journal of the Academic Marketing Science, 40, 413-433. http://dx.doi.org/10.1007/s11747-011-0261-6

Henseler, J. (2010). On the convergence of the partial least squares path modeling algorithm. Computer Statistics, $25,107-120$. http://dx.doi.org/10.1007/s00180-009-0164-x

Henseler, J., \& Fassott, G. (2010). Testing moderating effect in PLS path models: An illustration of available procedures. In V. Vinzi (Ed.), Handbook of Partial Least Squares (pp. 713-735). Berlin: Springer.

Homburg, C., Artz, M., \& Wieseke, J. (2012). Marketing performance measurement systems: Does comprehensiveness really improve performance? Journal of Marketing, 76(3), 56-77.

Jackson, M. (2008). Social and Economic Networks. New Jersey, USA: Princeton University Press.

Jansen, R., Curseu, P., Vermeulen, P., Geurts, J., \& Gibeus, P. (2011). Social capital as a decision aid in strategic decision-making in service organizations. Management Decision, 49(4), 734-747. http://dx.doi.org/10.1108/ 00251741111130823

Johannesson, J., \& Palona, I. (2010). Environmental turbulence and success of firm's intelligence strategy: Development of research instruments. International Journal of Management, 27(3), 448-458.

Kreiser, P., Marino, L., Kuratno, D., \& Weaver, K. (2013). Disaggregating entrepreneurial orientation: The non-linear impact of innovativeness, proactiveness and risk-taking on SME performance. Small Business Economics, 40(2), 273-291. http://dx.doi.org/10.1007/s11187-012-9460-x

Krejcie, \& Morgan. (1970). Determining Sample Size for Research Activities. Educational and psychological measurement, 30, 607-610.

Lumpkin, G., Cogliser, C., \& Scheneider, D. (2009). Understanding and measuring autonomy: An entrepreneurial orientation perspective. Entrepreneurship Theory and Practice, 33(1), 47-69. http://dx.doi.org/10.1111/j.1540-6520.2008.00280.x

Li, Y., Guo, H., Liu, Y., \& Li, M. (2008). Incentive mechanism, entrepreneurial orientation, and technology commercialization: Evident from China's transitional economy. The Journal of Product Innovation Management, 25, 63-78.

Lim, C., \& Putnam, R. (2010). Religion, social networks and life satisfaction. American Sociological Review, 75(6), 914-933.

Nunéz, E., \& Lynn, G. (2012). The impact of adding improvisation to sequential NPD processes on cost: The moderating effect of turbulence. Academy of Marketing Studies Journal, 16(1), 1-17.

Nagarajan, V., Savitskie, K., Ranganathan, S., Sen, S., \& Alexander, A. (2013). The effect of environmental uncertainty, information quality, and collaborative logistics on supply chain flexibility of small manufacturing firms in India. Asia Pacific Journal of Marketing and Logistics, 25(5), 784-802. http://dx.doi.org/10.1108/APJML-09-2011-0065

Miller, D., \& Friesen, P. (1978). Archetypes of strategy formulation. Management Science, 24(9), 921-933. http://dx.doi.org/10.1287/mnsc.24.9.921

Moreno, A., \& Casillas, J. (2008). Entrepreneurial orientation and growth of SMEs: A causal model. 
Entrepreneurial Theory and Practice, 32(3), 507-528.

Morgan, N., Vorhies, D., \& Mason, C. (2009). Marketing orientation, marketing capabilities, and firm performance. Strategic Management Journal, 30, 909-920.

Parra-Requena, G., Ruiz-Ortega, M., \& García-Villaverde, P. (2011). Towards pioneering through capabilities in dense and cohesive social networks. Journal of Business \& Industrial Marketing, 27(1), 41-52.

Peng, L., \& Sang, G. (2011). Bridging Western management theories and Japanese management practices: Case of the Toyota Way model. Emerald Emerging Case Studies, 1(1), 1-20.

Pirolo, L., \& Presutti, M. (2010). The impact of social capital on the start-ups' performance growth. Journal of Small Business Management, 48(2), 197-227. http://dx.doi.org/10.1111/j.1540-627X.2010.00292.x

Sundqvist, S., Kyläheiko, O., \& Cadogan, J. (2012). Kirznerian and Schumpeterian entrepreneurial-oriented behavior in turbulent export markets. International Marketing Review, 29(4), 494-509.

Sciascia, S., Mazzola, P., \& Chirico, F. (2012). Generation involvement in the top management team of family firms: Exploring nonlinear effect on entrepreneurial orientation. Entrepreneurship Theory and Practice, 37(1), 69-85. http://dx.doi.org/10.1111/j.1540-6520.2012.00528.x

Simon, M., Stanchel, C., \& Covin, J. (2011). The effect of entrepreneurial orientation and commitment to objective on performance. New England Journal of Entrepreneurship, 4(2), 9-17.

Shane, S. (2012). Reflection on the 2010 AMR decade award: Delivering on the promise of entrepreneurship as a field of research. Academy of Management Review, 37(1), 10-20.

Sheppard, R., \& Radulovich, L. (2010). Construction of a seasonal subjective performance instrument for a primary industry sector. The Journal of Applied Business and Economics, 10(4), 48-63.

Slater, S., Olson, E., \& Finnegan, C. (2011). Business strategy, marketing organization culture, and performance. Marketing Letter, 22, 227-242.

Spullberg, D. (2009). The Theory of the Firm: Microeconomics with Endogenous Entrepreneurs, Firm, Markets, and Organization. New York: Cambridge University Press.

Runyam, R., Ge, B., Dong, B., \& Swinney, L. (2008). Entrepreneurial orientation in cross- cultural research: Assessing measurement invariance in the construct. Entrepreneurship Theory and Practice, 36(4), 819-836.

Robert, J. (2008). The modern firm: Organizational design for performance and growth. New York: Oxford University Press.

Tang, Z., Kreizer, P., Marino, L., \& Weaver, K. (2010). Exploring proactiveness as a moderator in the process of perceiving industrial munificence: A field study of SMEs in four countries. Journal of Small Business Management, 48(2), 97-115. http://dx.doi.org/10.1111/j.1540-627X.2010.00288.x

Urkurt, C., Kumar, R., Kimzan, H., \& Eminoglu, G. (2013). Role of innovation in the relationship between organizational culture and firm performance: A study of the banking sector in Turkey. European Journal of Innovation Management, 16(1), 92-117. http://dx.doi.org/10.1108/14601061311292878

Zhang, J., \& Duan, Y. (2010). Empirical study on the impact of market orientation and innovation orientation on new product performance of Chinese manufacturers. Nankai Business Review International, 1(2), 214-231.

Wales, W., Gupta, V., \& Mousa, F. (2013). Empirical research on entrepreneurial orientation: An assessment and suggestions for future research. International Small Business Journal, 31(4), 357-383. http://dx.doi.org/10.1177/0266242611418261

Wang, H., \& Fang, S. (2012). The moderating effect of environmental uncertainty on the relationship between network structures and the innovative performance of a new venture. Journal of Business \& Industrial Marketing, 27(4), 311-323.

Wei, Y., Frankwick, G., \& Nguyen, B. (2012). Should firms consider employee input in reward system design? The effect of participation on market orientation and new product performance. The Journal of Product Innovation Management, 29(4), 546-558.

\section{Copyrights}

Copyright for this article is retained by the author(s), with first publication rights granted to the journal.

This is an open-access article distributed under the terms and conditions of the Creative Commons Attribution license (http://creativecommons.org/licenses/by/3.0/). 